\title{
ANALISIS PENGARUH NET INCOME, OPERATING CASH FLOW, DAN DEBT TO EQUITY RATIO TERHADAP DIVIDEND PER SHARE PADA PERUSAHAAN MANUFAKTUR YANG TERDAFTAR DI BURSA EFEK INDONESIA
}

\author{
Michelle dan Vidyarto Nugroho \\ Fakultas Ekonomi Universitas Tarumanagara \\ Email:michellegraciad@gmail.com dan Email:vidyartonugroho@yahoo.co.id
}

\begin{abstract}
The purpose of this study is to examine the effect of net income (EAT), operating cash flow (OCF), and debt to equity ratio (DER) towards dividend per share (DPS) on manufacturing companies listed on the Indonesia Stock Exchange in 2012-2015. The sampling method used was purposive sampling. The number of samples that met the criteria was 172 companies. Data were analyzed using multiple linear regression analysis. The results showed that, simultaneously, all variables had significant effect on DPS. Partially, the variable that had significant effect was EAT, while OCF and DER had no significant effect. Furthermore, the coefficient of determination $\left(\mathrm{R}^{2}\right)$ showed that the effect of variables EAT, OCF, and DER simultaneously to DPS was 30,3\%.
\end{abstract}

Keywords: dividend per share, net income, operating cash flow, debt to equity ratio

Abstrak: Tujuan penelitian ini adalah mengetahui pengaruh net income (EAT), operating cash flow $(O C F)$, dan debt to equity ratio $(D E R)$ terhadap dividend per share $(D P S)$ pada perusahaan manufaktur yang terdaftar di Bursa Efek Indonesia tahun 2012-2015. Metode pengumpulan sampel dilakukan dengan purposive sampling. Jumlah sampel yang memenuhi kriteria sebanyak 172 perusahaan. Teknik analisis data menggunakan analisis regresi linier berganda. Hasil penelitian menunjukkan bahwa secara simultan, semua variabel berpengaruh signifikan terhadap DPS. Secara parsial, variabel yang berpengaruh signifikan adalah EAT, sedangkan $O C F$ dan $D E R$ tidak signifikan. Selain itu, hasil koefisien determinasi $\left(\mathrm{R}^{2}\right)$ menunjukkan bahwa pengaruh variabel $E A T, O C F$, dan DER secara simultan terhadap DPS sebesar 30,3\%.

Kata kunci: dividen per lembar saham, laba bersih, arus kas operasi, rasio hutang terhadap ekuitas

\section{PENDAHULUAN}

Perkembangan industri di Indonesia yang pesat saat ini, membuat setiap perusahaan berupaya untuk mempertahankan dan mengembangkan usahanya. Mulai dari perusahaan kecil sampai besar tentu membutuhkan modal dalam menjalankan kegiatan usahanya. Pembiayaan modal tersebut dapat diperoleh dari dalam perusahaan (internal) dan dari luar perusahaan (eksternal). Pembiayaan modal internal berasal dari laba ditahan (retained earnings) perusahaan, sedangkan pembiayaan modal eksternal berasal dari penjualan saham perusahaan kepada calon investor di pasar modal.

Setiap investor yang menanamkan modal dengan membeli saham suatu perusahaan pasti mengharapkan pengembalian atas investasinya. Menurut Pradhono (2004:149), bentuk pengembalian investasi adalah berupa capital gain dan dividen. Capital gain merupakan keuntungan yang diperoleh dari selisih antara harga jual saham dan harga 
belinya. Dividen adalah laba perusahaan yang dibagikan kepada para pemegang saham. Tingkat pembagian dividen perusahaan tergantung pada kebijakan dividen perusahaan. Menurut Sawir (2004:137), kebijakan dividen merupakan keputusan apakah laba akan dibayarkan sebagai dividen atau ditahan untuk reinvestasi dalam perusahaan. Pengertian dividen per lembar saham menurut Irawati (2006:64) adalah besarnya dividen yang akan dibagikan kepada investor setelah dibandingkan dengan rata-rata tertimbang saham biasa yang beredar. Dividen kas adalah jenis dividen yang paling umum dibagikan kepada investor.

Tujuan utama dari kegiatan usaha perusahaan adalah memperoleh laba. Menurut Gade (2005:16), laba yang diperoleh perusahaan adalah selisih antara pendapatan dan biaya. Laba dapat digunakan sebagai indikator kinerja perusahaan, karena dalam menilai tingkat kualitas kinerja suatu perusahaan dapat dilihat dari tingkat laba yang diperoleh perusahaan tersebut. Informasi laba yang mencerminkan kinerja perusahaan memiliki kemungkinan dapat mempengaruhi pembagian dividen. Menurut Sartono (2010:66), debt to equity ratio merupakan rasio hutang terhadap modal, yang mengukur pembiayaan perusahaan melalui hutang. Perusahaan akan mengutamakan pelunasan hutang sehingga dapat mempengaruhi tingkat laba.

Perusahaan yang menjual sahamnya ke publik di pasar modal, mempunyai kewajiban untuk melaporkan laporan keuangannya secara terbuka. Menurut Harahap (2010:257), laporan arus kas memberikan informasi yang relevan tentang penerimaan dan pengeluaran kas suatu perusahaan pada suatu periode tertentu, dengan adanya klasifikasi transaksi pada kegiatan : operasi, pembiayaan, dan investasi. Jumlah arus kas dari kegiatan operasi merupakan indikator apakah kegiatan operasi perusahaan menghasilkan kas yang cukup untuk melunasi pinjaman, membayar dividen, dan kegiatan lainnya.

Beberapa penelitian terdahulu telah dilakukan untuk menganalisis faktor-faktor yang mempengaruhi dividend per share suatu perusahaan. Wowor dan Mangantar (2014) melakukan penelitian yang menganalisis pengaruh laba bersih dan tingkat risiko harga saham terhadap dividen yang dijelaskan dengan dividend per share. Hasil penelitiannya adalah laba bersih berpengaruh positif dan signifikan, sedangkan tingkat risiko harga saham berpengaruh negatif dan signifikan. Isnaeni dan Herjdiono (2015) melakukan penelitian mengenai pengaruh laba bersih, arus kas operasi, leverage, dan dividen tahun sebelumnya terhadap dividen. Hasil penelitian menyatakan bahwa laba bersih, arus kas operasi dan pembayaran dividen tahun sebelumnya berpengaruh positif dan signifikan, sedangkan leverage yang dijelaskan dengan debt to equity ratio tidak berpengaruh. Penelitian yang dilakukan oleh Ramli dan Arfan (2011) mengenai pengaruh laba, arus kas operasi, arus kas bebas, dan pembayaran dividen kas sebelumnya terhadap dividen yang dijelaskan dengan dividend per share menyatakan bahwa semua variabel berpengaruh positif kecuali arus kas operasi yang memiliki pengaruh negatif.

Penelitian yang dilakukan oleh Ikhsan (2014) mengenai pengaruh debt to equity ratio, return on investment, kepemilikan manajerial dan ukuran perusahaan terhadap dividend per share. Hasilnya menyatakan bahwa debt to equity ratio, return on investment, dan ukuran perusahaan mempunyai pengaruh yang signifikan, sedangkan kepemilikan manajerial tidak signifikan. Penelitian lainnya dilakukan oleh Martati (2010) yang meliputi faktor penentu dividend per share menemukan bahwa earning per share dan dividend per share tahun sebelumnya memiliki pengaruh signifikan, sedangkan current ratio, debt to equity ratio, dan total asset turnover tidak mempengaruhi dividend per share. Adanya perbedaan hasil antara penelitian-penelitian tersebut mendorong 
dilakukannya penelitian ini untuk mengetahui apakah terdapat pengaruh dari faktor-faktor tersebut terhadap dividen per lembar saham perusahaan.

Perumusan masalah dalam penelitian ini adalah (1) apakah terdapat pengaruh net income terhadap dividend per share, (2) apakah terdapat pengaruh operating cash flow terhadap dividend per share, (3) apakah terdapat pengaruh debt to equity ratio terhadap dividend per share.

Tujuan penelitian ini adalah untuk mengetahui (a) pengaruh net income terhadap dividend per share, (b) pengaruh operating cash flow terhadap dividend per share, (c) pengaruh debt to equity ratio terhadap dividend per share.

\section{KAJAIN TEORI}

Dividen. Dividen adalah pendistribusian porsi keuntungan perusahaan yang dibayarkan ke pemegang saham. Dividen sering dinyatakan dalam bentuk nilai nominal uang untuk setiap saham yang menerimanya atau disebut dengan dividen per lembar saham (Guinan, 2009:78). Dividen per lembar saham adalah besarnya dividen yang akan diterima oleh pemegang saham untuk setiap saham yang dimiliki (Scott, 2015:190). Menurut Khan dan Jain (2010:6.24), dividend per share adalah jumlah dividen yang dibagikan oleh perusahaan kepada pemegang saham untuk setiap saham biasa yang beredar.

Net Income. Laba bersih merupakan selisih dari pendapatan dengan biaya, yang disesuaikan dengan keuntungan atau kerugian. Laba bersih dapat digunakan sebagai indikator dividen karena menunjukkan suatu kondisi tertentu dari kinerja perusahaan. Laba bersih menjadi bahan pertimbangan bagi manajemen perusahaan dalam menentukan jumlah dividen yang akan dibagikan kepada investor (Weil, Schipper, dan Francis, 2014:16). Menurut Needles, Powers, dan Crosson (2014:86) net income merupakan peningkatan bersih dalam ekuitas pemilik yang diperoleh dari kegiatan operasi perusahaan.

Operating Cash Flow. Laporan arus kas melaporkan arus kas selama periode tertentu dan diklasifikasikan menurut aktivitas operasi, investasi, dan pendanaan. Aktivitas operasi adalah aktivitas penghasil utama pendapatan entitas dan aktivitas lain yang bukan merupakan aktivitas investasi dan aktivitas pendanaan. Jumlah arus kas yang timbul dari aktivitas operasi adalah indikator utama untuk menentukan apakah operasi entitas telah menghasilkan arus kas yang cukup untuk melunasi pinjaman, memelihara kemampuan operasi entitas, membayar dividen, dan melakukan investasi baru tanpa bantuan sumber pendanaan dari luar (PSAK No. 2 Penyesuaian 2014, IAI:2015). Menurut Libby, Libby, dan Short (2011:639), operating cash flow adalah kas masuk dan kas keluar yang berkaitan langsung dengan pendapatan dan biaya yang dilaporkan dalam laporan laba rugi.

Debt to Equity Ratio. Rasio hutang terhadap ekuitas adalah perhitungan yang menentukan kemampuan perusahaan membayar hutang jangka panjang, dengan membandingkan total hutang dengan total ekuitas pemegang saham. Dalam perspektif kemampuan membayar hutang jangka panjang, makin rendah rasio hutang terhadap ekuitas, makin baik posisi hutang perusahaan (Gibson, 2013:285). Menurut Weil, Schipper, dan Francis (2014:236), debt to equity ratio merupakan rasio hutang yang digunakan untuk mengukur leverage perusahaan, dengan cara membagi total hutang perusahaan dengan total ekuitas. 


\section{Kerangka Pemikiran}

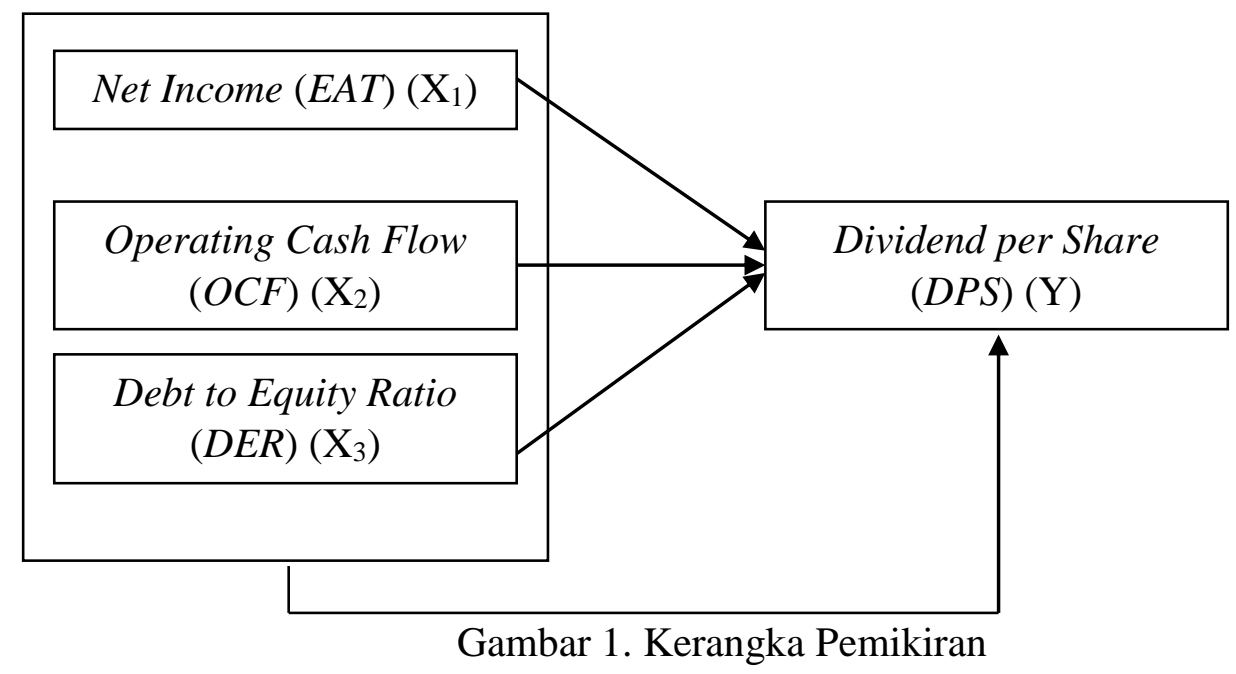

Pengembangan Hipotesis. Pengaruh Net Income (EAT) terhadap Dividend per Share (DPS). Dividen merupakan laba yang diperoleh perusahaan dan dibagikan kepada para investor berdasarkan jumlah sahamnya. Laba yang dibagikan kepada investor adalah laba bersih perusahaan setelah dikurangi dengan pajak (earnings after tax). Laba bersih dapat dijadikan sebagai alat ukur dividen karena mencerminkan kinerja perusahaan. Selain itu, laba bersih juga merupakan dasar pertimbangan bagi manajemen perusahaan dalam menentukan besarnya pembagian dividen. Makin tinggi laba bersih yang dihasilkan oleh perusahaan maka makin tinggi pula dividennya. Sebaliknya, apabila terjadi penurunan pembagian dividen, dapat disimpulkan bahwa perusahaan sedang mengalami penurunan laba. Pembagian dividen menjadi sinyal bagi para investor dalam melihat prospek masa depan suatu perusahaan, karena penurunan pembagian dividen memiliki pengaruh yang negatif terhadap harga saham. Apabila tingkat pembagian dividen rendah, minat investor dalam menanamkan modalnya tentu akan menurun, diikuti dengan harga saham perusahaan yang juga menurun. Hal ini yang menjadi tanggungjawab bagi manajemen perusahaan dalam pengelolaan laba bagi masa depan perusahaan. Berdasarkan uraian tersebut, maka perumusan hipotesis dalam penelitian ini adalah:

$\mathbf{H}_{1}=$ Terdapat pengaruh positif yang signifikan EAT terhadap DPS

Pengaruh Operating Cash Flow (OCF) terhadap Dividend per Share (DPS). Arus kas operasi (operating cash flow) adalah arus kas yang berasal dari kegiatan operasi sebagai penghasil utama pendapatan yang diperoleh perusahaan. Jumlah arus kas operasi dapat dijadikan sebagai indikator penentuan kegiatan operasi perusahaan dalam menghasilkan arus kas yang cukup untuk melakukan pembayaran dividen. Oleh karena itu, makin besar arus kas operasi suatu perusahaan maka makin besar pula dividennya. Arus kas operasi juga menunjukkan kinerja perusahaan, yang berarti apabila suatu perusahaan memiliki arus kas operasi yang besar maka dapat dikatakan perusahaan tersebut memiliki kinerja yang baik. Berdasarkan uraian tersebut, maka perumusan hipotesis dalam penelitian ini adalah:

$\mathbf{H}_{2}=$ Terdapat pengaruh positif yang signifikan $O C F$ terhadap $D P S$ 
Pengaruh Debt to Equity Ratio (DER) terhadap Dividend per Share (DPS). Debt to equity ratio merupakan rasio hutang terhadap ekuitas, sebagai gambaran sejauh mana perusahaan dibiayai oleh hutang. Peningkatan debt to equity ratio akan mempengaruhi tingkat laba bersih yang tersedia bagi investor, maka makin tinggi kewajiban perusahaan akan menyebabkan makin rendahnya tingkat kemampuan perusahaan dalam melakukan pembayaran dividennya. Hal ini dikarenakan perusahaan akan memprioritaskan laba yang diperoleh untuk membayar atau melunasi hutang dan sisanya akan dibagikan sebagai dividen. Berdasarkan uraian tersebut, maka perumusan hipotesis dalam penelitian ini adalah:

$\mathbf{H}_{3}$ = Terdapat pengaruh negatif yang signifikan DER terhadap DPS

\section{METODE}

Pemilihan Obyek Penelitian dan Metode Pemilihan Sampel. Penelitian ini dilakukan pada perusahaan manufaktur yang terdaftar di Bursa Efek Indonesia (BEI) dengan pengamatan dan analisis obyek penelitian. Obyek penelitian dalam penelitian ini adalah pengaruh net income, operating cash flow, dan debt to equity ratio terhadap dividend per share.

Populasi yang digunakan dalam penelitian ini adalah perusahaan manufaktur yang terdaftar di Bursa Efek Indonesia (BEI) yang menerbitkan laporan keuangan tahunan selama periode tahun 2012-2015 yang dipublikasikan di BEI. Penarikan sampel dilakukan dengan menggunakan metode purposive sampling, yaitu teknik pengambilan sampel berdasarkan kriteria tertentu. Kriteria penelitian yang digunakan adalah (1) perusahaan manufaktur yang terdaftar berturut-turut di BEI selama periode penelitian yaitu tahun 2012-2015, (2) perusahaan manufaktur yang menerbitkan laporan keuangan tahunan menggunakan mata uang Rupiah, (3) perusahaan manufaktur yang tidak mengalami kerugian, (4) perusahaan manufaktur yang laporan keuangannya berakhir pada periode 31 Desember, (5) perusahaan manufaktur yang membagikan dividen, (6) perusahaan manufaktur yang memiliki arus kas operasi positif.

Tabel 1. Definisi Variabel dan Pengukuran

\begin{tabular}{|c|c|c|}
\hline Variabel & Definisi & Cara Pengukuran \\
\hline \multicolumn{3}{|l|}{ a. Dependen } \\
\hline \multirow[t]{2}{*}{ Dividend per Share (DPS) } & \multirow{2}{*}{$\begin{array}{l}\text { Jumlah dividen yang } \\
\text { dibagikan perusahaan untuk } \\
\text { setiap saham biasa yang } \\
\text { beredar }\end{array}$} & Dividen \\
\hline & & $\overline{\text { Jumlah saham beredar }}$ \\
\hline \multicolumn{3}{|l|}{ b. Independen } \\
\hline Net Income (EAT) & $\begin{array}{l}\text { Peningkatan bersih dalam } \\
\text { ekuitas pemilik yang } \\
\text { diperoleh dari kegiatan } \\
\text { operasi perusahaan }\end{array}$ & $\begin{array}{l}\text { Laba sebelum pajak }(E B T) \text { - } \\
\text { Pajak }\end{array}$ \\
\hline $\begin{array}{l}\text { Operating Cash Flow } \\
(O C F)\end{array}$ & $\begin{array}{l}\text { Selisih antara arus kas } \\
\text { masuk dan arus kas keluar } \\
\text { yang berasal dari aktivitas }\end{array}$ & $\begin{array}{l}\text { Laba sebelum bunga dan } \\
\text { pajak }(E B I T)-\text { Pajak + } \\
\text { Depresiasi }\end{array}$ \\
\hline
\end{tabular}


Michelle dan Nugroho: Analisis Pengaruh Income, Operating Cash Flow dan Debt...

\begin{tabular}{|c|c|c|c|}
\hline \multirow{3}{*}{ Debt to Equity Ratio (DER) } & \multicolumn{3}{|l|}{ operasi } \\
\hline & Rasio & hutang & Total hutang \\
\hline & $\begin{array}{l}\text { membagi } \\
\text { perusahaan } \\
\text { ekuitas }\end{array}$ & $\begin{array}{l}\text { total hutang } \\
\text { dengan total }\end{array}$ & $\overline{\text { Total ekuitas }}$ \\
\hline
\end{tabular}

Metode Pengumpulan Data. Pada penelitian ini, pengumpulan data dilakukan melalui studi kepustakaan, yaitu dengan cara mengumpulkan data dan informasi yang diperoleh dari buku-buku ilmiah, jurnal-jurnal ilmiah, dan sumber tertulis lainnya baik dari media massa maupun elektronik yang berkaitan dengan masalah yang diteliti. Data yang diperlukan dalam penelitian ini yaitu data sekunder berupa laporan keuangan tahunan perusahaan manufaktur yang terdaftar di BEI selama periode penelitian tahun 2012-2015. Data tersebut diperoleh dari media internet melalui situs resmi BEI yaitu www.idx.co.id.

Teknik Analisis Data. Teknik analisis data yang digunakan dalam penelitian ini adalah teknik analisis statistik dan hasil pengolahan data diperoleh melalui alat bantu analisis berupa program SPSS (Statistical Product and Service Solution) versi 23. Data penelitian ini berdasarkan pada laporan keuangan tahunan periode tahun 2012-2015 yang diterbitkan oleh perusahaan manufaktur di BEI yang memenuhi kriteria penelitian.

\section{HASIL DAN PEMBAHASAN}

Teknik analisis data terdiri dari uji normalitas, pengujian statistik deskriptif, pengujian asumsi klasik yang harus dipenuhi dalam model regresi, analisis regresi linier berganda, dan pengujian terhadap hipotesis yang meliputi uji $\mathrm{t}$ secara parsial dan uji $\mathrm{F}$ secara simultan, serta pengujian koefisien determinasi. Hasil analisis data diperoleh melalui alat bantu analisis yaitu program SPSS versi 23.

1. Pengujian Statistik Deskriptif. Langkah pertama yang dilakukan dalam proses analisis data penelitian ini adalah pengujian statistik deskriptif. Dalam pengujian ini, diperoleh gambaran dari data dan karakteristik sampel, yang terdiri dari nilai minimum, maksimum, rata-rata (mean), dan standar deviasi setiap variabel yang digunakan dalam penelitian ini. Data hasil pengujian statistik deskriptif dapat dilihat pada Tabel 3. di bawah ini.

Tabel 3. Hasil Uji Statistik Deskriptif

\begin{tabular}{lrrrrr}
\multicolumn{7}{c}{ Descriptive Statistics } \\
\hline LnEAT & \multicolumn{1}{c}{ Minimum } & Maximum & \multicolumn{1}{c}{ Mean } & Std. Deviation \\
LnOCF & 172 & 21.39 & 30.76 & 26.2731 & 2.02803 \\
DER & 172 & 17.75 & 30.90 & 26.2266 & 2.18658 \\
LnDPS & 172 & .09 & 5.20 & .8715 & .86381 \\
Valid N (listwise) & 172 & -1.43 & 8.78 & 3.9347 & 1.91858 \\
\hline
\end{tabular}


2. Pengujian Asumsi Klasik. Langkah berikutnya dalam analisis data penelitian ini adalah pengujian asumsi klasik. Pengujian asumsi klasik meliputi uji normalitas, multikolinearitas, autokorelasi, dan heteroskedastisitas.

a. Uji Normalitas. Uji normalitas merupakan langkah awal yang dilakukan dalam penelitian untuk menguji apakah dalam suatu model regresi, sampel penelitiannya baik variabel dependen maupun independen apakah memiliki distribusi yang normal atau tidak. Kenormalan data dapat dilihat dari residualnya. Pada penelitian ini, digunakan metode Kolmogorov Smirnov $(K S)$ yang terdapat dalam program SPSS. Langkah pertama adalah menyusun hipotesis: $\mathrm{H}_{0}=$ Residual berdistribusi normal dan $\mathrm{H}_{1}=$ Residual tidak berdistribusi normal. Selanjutnya adalah dengan memilih tingkat signifikansi $\alpha$. Langkah berikutnya adalah menentukan keputusan uji normalitasnya, dimana jika nilai $=0.05<$ Sig. maka $\mathrm{H}_{0}$ diterima atau tidak ditolak yang berarti sampel data berdistribusi dengan normal. Data hasil pengujian normalitas dapat dilihat pada Tabel 4. berikut ini.

Tabel 4. Hasil Uji Kolmogorov Smirnov $(K S)$

One-Sample Kolmogorov-Smirnov Test

\begin{tabular}{llr}
\hline & & Unstandardized Residual \\
$N$ & & 172 \\
Normal Parameters ${ }^{a, b}$ & Mean & .0000000 \\
& Std. Deviation & 1.58748596 \\
Most Extreme Differences & Absolute & .062 \\
& Positive & .062 \\
& Negative & -.053 \\
Test Statistic & .062 \\
Asymp. Sig. (2-tailed) & $.200^{\mathrm{c}, \mathrm{d}}$ \\
\hline a. Test distribution is Normal. \\
b. Calculated from data. \\
c. Lilliefors Significance Correction. \\
d. This is a lower bound of the true significance.
\end{tabular}

Dari Tabel 4. tersebut ditunjukkan bahwa $\alpha<$ Asymp. Sig. (2-tailed) dengan tingkat signifikansi sebesar 0,200 yang lebih besar dari 0,05. Hal ini menunjukkan bahwa $\mathrm{H}_{0}$ diterima atau tidak ditolak, yang berarti data telah terdistribusi dengan normal sehingga layak untuk diuji.

b. Uji Multikolinearitas. Uji multikolinearitas bertujuan untuk menguji apakah ditemukan adanya korelasi antar variabel independen dalam model regresi. Apabila terdapat korelasi antar variabel independen, artinya adalah terdapat masalah multikolinearitas. Dalam sebuah model regresi yang baik, seharusnya tidak terdapat multikolinearitas, dengan kata lain tidak ada korelasi yang kuat antar variabel independennya.

Untuk melihat apakah terdapat multikolinearitas dalam suatu model regresi, dapat ditunjukkan dari nilai VIF (Variance Inflation Factor). Apabila nilai VIF $>10$ menunjukkan adanya gejala multikolinearitas, sedangkan jika nilai $V I F<10$ berarti tidak terjadi multikolinearitas. Data hasil pengujian multikolinearitas dapat dilihat pada tabel 5 . berikut ini. 
Tabel 5. Hasil Uji Multikolinearitas (1)

\begin{tabular}{|c|c|c|c|c|c|c|c|c|}
\hline \multicolumn{9}{|c|}{ Coefficients $^{a}$} \\
\hline & & \multicolumn{2}{|c|}{$\begin{array}{c}\text { Unstandardized } \\
\text { Coefficients }\end{array}$} & $\begin{array}{c}\text { Standardized } \\
\text { Coefficients }\end{array}$ & \multirow[b]{2}{*}{$t$} & \multirow[b]{2}{*}{ Sig. } & \multicolumn{2}{|c|}{$\begin{array}{l}\text { Collinearity } \\
\text { Statistics }\end{array}$} \\
\hline \multicolumn{2}{|c|}{ Model } & $B$ & $\begin{array}{l}\text { Std. } \\
\text { Error }\end{array}$ & Beta & & & Tolerance & $V I F$ \\
\hline 1 & (Constant) & -10.211 & 1.629 & & -6.267 & .000 & & \\
\hline & LnEAT & .535 & .121 & .565 & 4.412 & .000 & .248 & 4.029 \\
\hline & LnOCF & .000 & .112 & .000 & .002 & .998 & .252 & 3.972 \\
\hline & $D E R$ & .102 & .148 & .046 & .691 & .490 & .915 & 1.093 \\
\hline
\end{tabular}

a. Dependent Variable: LnDPS

Dari Tabel 5 tersebut ditunjukkan bahwa nilai VIF untuk EAT sebesar 4,029, nilai $V I F$ untuk $O C F$ sebesar 3,972, dan nilai VIF untuk DER sebesar 1,093. Hal ini menunjukkan bahwa semua variabel independen yang digunakan dalam penelitian ini tidak terdapat VIF yang nilainya melebihi 10, artinya adalah tidak terjadi multikolinearitas antar variabel independen, sehingga memenuhi syarat menjadi data yang baik dan layak diuji. Berdasarkan hasil perhitungan pada tabel 5. tersebut, nilai tolerance variabel independen tidak ada yang kurang dari 0,10 dimana nilai tolerance untuk EAT sebesar 0,248 , nilai tolerance untuk $O C F$ sebesar 0,252 , dan nilai tolerance untuk DER sebesar 0,915 . Hal ini menunjukkan bahwa tidak adanya korelasi antar variabel independen yang nilainya melebihi 95\%. Setelah melihat hasil uji multikolinearitas pada tabel 5. tersebut, maka untuk melihat apakah terdapat korelasi yang tinggi antar variabel independen dapat juga dilihat dari Tabel 6 sebagai berikut.

Tabel 6. Hasil Uji Multikolinearitas (2)

\begin{tabular}{|c|c|c|c|c|c|}
\hline \multicolumn{6}{|c|}{ Coefficient Correlations ${ }^{a}$} \\
\hline & & & $D E R$ & LnOCF & LnEAT \\
\hline \multirow[t]{6}{*}{1} & Correlations & $D E R$ & 1.000 & -.266 & .290 \\
\hline & & LnOCF & -.266 & 1.000 & -.865 \\
\hline & & LnEAT & .290 & -.865 & 1.000 \\
\hline & Covariances & $D E R$ & .022 & -.004 & .005 \\
\hline & & $\mathrm{LnOCF}$ & -.004 & .012 & -.012 \\
\hline & & LnEAT & .005 & -.012 & .015 \\
\hline
\end{tabular}

a. Dependent Variable: LnDPS

Dari Tabel 6. tersebut ditunjukkan bahwa hanya variabel EAT yang memiliki korelasi cukup tinggi dengan variabel $O C F$ yaitu dengan tingkat korelasi sebesar - 0,865 atau sekitar 86,5\%, sedangkan tingkat korelasi variabel EAT dan DER sebesar 0,290 atau sekitar 29\% dan tingkat korelasi variabel $O C F$ dan DER sebesar - 0,266 atau sekitar $26,6 \%$. Oleh karena nilai korelasi masih di bawah 95\%, maka dapat disimpulkan bahwa tidak terjadi multikolinearitas yang serius. Hal ini menunjukkan kesesuaian dengan hasil perhitungan pada tabel 5. sebelumnya, dimana berdasarkan hasil perhitungan nilai VIF dan tolerance, tidak terdapat korelasi antar variabel independen yang nilainya lebih dari $95 \%$. Jadi dapat ditarik kesimpulan bahwa tidak terjadi multikolinearitas antar variabel independen dalam model regresi, sehingga data dikatakan baik dan layak diuji. 
c. Uji Autokorelasi. Autokorelasi terjadi apabila pengukuran variabel dilakukan dalam interval waktu tertentu. Penelitian ini menggunakan uji Durbin-Watson $(D W)$ untuk memeriksa apakah terdapat autokorelasi dalam model regresi. Langkah pertama yang dilakukan adalah menyusun hipotesis: $\mathrm{H}_{0}=$ Tidak ada autokorelasi dan $\mathrm{H}_{1}=$ Ada autokorelasi. Langkah selanjutnya adalah memilih tingkat signifikansi $\alpha$ dan dasar pengambilan keputusan berdasarkan hasil output SPSS kolom Durbin-Watson $(D W)$ serta tabel pengambilan keputusan Durbin-Watson $(D W)$ yang disajikan pada tabel 2. Data hasil pengujian autokorelasi dapat dilihat pada tabel 7. berikut ini.

Tabel 7. Hasil Uji Autokorelasi

\begin{tabular}{|c|c|c|c|c|c|}
\hline \multicolumn{6}{|c|}{ Model Summary ${ }^{b}$} \\
\hline Model & $R$ & $R$ Square & $\begin{array}{l}\text { Adjusted } R \\
\text { Square }\end{array}$ & $\begin{array}{l}\text { Std. Error of } \\
\text { the Estimate }\end{array}$ & $\begin{array}{l}\text { Durbin- } \\
\text { Watson }\end{array}$ \\
\hline 1 & $.562^{\mathrm{a}}$ & .315 & .303 & 1.60155 & 1.907 \\
\hline
\end{tabular}

Dari Tabel 7 tersebut ditunjukkan bahwa nilai $D W$ sebesar 1,907 (d), nilai ini dibandingkan dengan nilai tabel dengan menggunakan nilai signifikansi 0,05 , jumlah sampel penelitian sebesar 172 (n) dan jumlah variabel independen $3(\mathrm{k}=3)$. Syarat $\mathrm{H}_{0}$ diterima berdasarkan tabel pengambilan keputusan $D W$ adalah $d_{U} \leq d \leq 4-d_{U}$. Berdasarkan tabel Durbin-Watson, diperoleh nilai $d_{U}$ sebesar 1,7861 dan nilai $d_{L}$ sebesar 1,7152. Maka apabila nilai tersebut dimasukkan ke dalam persamaan $d_{U} \leq d \leq 4-d_{U}$ menjadi $1,7861<1,907<4-1,7861$. Hasilnya adalah $1,7861<1,907<2,2139$. Hal ini menunjukkan bahwa $\mathrm{H}_{0}$ diterima atau tidak ditolak, yang berarti dalam model regresi ini tidak terdapat autokorelasi, baik autokorelasi positif maupun autokorelasi negatif sesuai dengan tabel pengambilan keputusan $D W$ pada tabel 2.

d. Uji Heteroskedastisitas. Uji heteroskedastisitas bertujuan untuk menguji apakah dalam model regresi terjadi ketidaksamaan varian dari residual suatu pengamatan ke pengamatan lain. Apabila varian dari residual suatu pengamatan ke pengamatan yang lain berbeda disebut dengan heteroskedastisitas. Suatu model regresi dikatakan baik jika tidak terjadi heteroskedastisitas. Pada penelitian ini, digunakan uji Glejser untuk menguji apakah terdapat heteroskedastisitas dalam model regresi. Apabila variabel independen signifikan secara statistik memiliki pengaruh terhadap variabel dependen, maka ada indikasi bahwa terjadi heteroskedastisitas. Data hasil pengujian heteroskedastisitas dapat dilihat pada Tabel 8. di bawah ini.

Tabel 8. Hasil Uji Heteroskedastisitas

\begin{tabular}{|c|c|c|c|c|c|c|}
\hline \multicolumn{7}{|c|}{ Coefficients $^{a}$} \\
\hline \multirow[b]{2}{*}{ Model } & & Unstandardizec & Coefficients & $\begin{array}{c}\text { Standardized } \\
\text { Coefficients }\end{array}$ & \multirow[b]{2}{*}{$t$} & \multirow[b]{2}{*}{ Sig. } \\
\hline & & $B$ & Std. Error & Beta & & \\
\hline 1 & (Constant) & 3.175 & .993 & & 3.196 & .002 \\
\hline & LnEAT & -.125 & .074 & -.257 & -1.688 & .093 \\
\hline & $\mathrm{LnOCF}$ & .056 & .068 & .124 & .818 & .414 \\
\hline & $D E R$ & -.134 & .090 & -.117 & -1.481 & .141 \\
\hline
\end{tabular}


Dari Tabel 8 tersebut ditunjukkan bahwa tidak ada variabel independen yang signifikan secara statistik mempengaruhi variabel dependen nilai absolute residual (AbsRes). Hal ini dapat dilihat dari probabilitas signifikansi semua variabel independen yang berada di atas tingkat kepercayaan 5\% atau 0,05, dimana nilai signifikansi variabel EAT sebesar 0,093, nilai signifikansi variabel $O C F$ sebesar 0,414 , dan nilai signifikansi variabel $D E R$ sebesar 0,141. Jadi kesimpulannya adalah dalam model regresi tidak terdapat heteroskedastisitas, sehingga data dikatakan baik dan layak diuji.

3. Analisis Regresi Linier Berganda. Setelah dilakukan pengujian asumsi klasik, dapat diambil kesimpulan bahwa data-data yang digunakan dalam penelitian ini tidak terjadi gejala multikolinearitas, autokorelasi, dan heteroskedastisitas serta telah memenuhi asumsi normalitas sehingga layak untuk diuji. Oleh karena itu, selanjutnya dilakukan analisis regresi linier berganda yang bertujuan untuk menganalisis pengaruh net income (EAT), operating cash flow (OCF), dan debt to equity ratio (DER) terhadap dividend per share $(D P S)$ pada perusahaan manufaktur yang terdaftar di BEI. Data hasil analisis regresi linier berganda dapat dilihat pada tabel 9 . berikut ini.

Tabel 9. Hasil Analisis Regresi Linier Berganda

Coefficients $^{a}$

\begin{tabular}{|c|c|c|c|c|c|c|}
\hline \multirow{2}{*}{\multicolumn{2}{|c|}{ Model }} & \multicolumn{2}{|c|}{$\begin{array}{c}\text { Unstandardized } \\
\text { Coefficients }\end{array}$} & \multirow{2}{*}{$\begin{array}{c}\begin{array}{c}\text { Standardized } \\
\text { Coefficients }\end{array} \\
\text { Beta }\end{array}$} & \multirow[b]{2}{*}{$t$} & \multirow[b]{2}{*}{ Sig. } \\
\hline & & $B$ & Std. Error & & & \\
\hline \multirow[t]{4}{*}{1} & (Constant) & -10.209 & 1.629 & & -6.265 & .000 \\
\hline & LnEAT & .535 & .121 & .565 & 4.411 & .000 \\
\hline & $\mathrm{LnOCF}$ & .000 & .112 & .000 & .004 & .997 \\
\hline & $D E R$ & .102 & .148 & .046 & .690 & .491 \\
\hline
\end{tabular}

Sesuai dengan Tabel 9. di atas dapat dibentuk persamaan regresi linier berganda penelitian ini sebagai berikut:

$$
Y=-10,209+0,535 X_{1}+0,000 X_{2}+0,102 X_{3}+e
$$

Keterangan: $\mathrm{Y}=$ Dividend per Share $(D P S) ; \mathrm{X}_{1}=$ Net Income $(E A T) ; \mathrm{X}_{2}=$ Operating Cash Flow $(O C F) ; \mathrm{X}_{3}=$ Debt to Equity Ratio $(D E R) ; \mathrm{e} \quad=$ error.

Berdasarkan hasil persamaan regresi linier berganda dalam tabel 9. diperoleh koefisien untuk variabel EAT $\left(\mathrm{X}_{1}\right)$ sebesar 0,535, variabel $O C F\left(\mathrm{X}_{2}\right)$ sebesar 0,000, dan variabel $D E R\left(\mathrm{X}_{3}\right)$ sebesar 0,102. Selain itu juga diperoleh konstanta sebesar - 10,209. Sesuai dengan model persamaan regresi linier berganda tersebut menunjukkan hasil bahwa variabel EAT berpengaruh positif terhadap DPS, dengan kata lain apabila net income mengalami kenaikan maka dividend per share akan mengalami kenaikan pula. Kenaikan satu satuan variabel EAT akan menaikkan DPS sebesar 0,535 satuan, jika variabel independen lainnya di dalam model regresi dianggap konstan.

Begitu pula dengan variabel $O C F$ berpengaruh positif terhadap $D P S$, dengan kata lain apabila operating cash flow mengalami kenaikan maka dividend per share akan mengalami kenaikan pula. Kenaikan satu satuan variabel $O C F$ akan menaikkan DPS sebesar 0,000 satuan, jika variabel independen lainnya di dalam model regresi dianggap konstan. 
Variabel $D E R$ juga berpengaruh positif terhadap DPS, dengan kata lain apabila debt to equity ratio mengalami kenaikan maka dividend per share akan mengalami kenaikan pula. Kenaikan satu satuan variabel DER akan menaikkan DPS sebesar 0,102 satuan, jika variabel independen lainnya di dalam model regresi dianggap konstan.

4. Analisis Hipotesis. Pertama. Uji t (Uji Parsial). Uji t dilakukan dengan tujuan untuk mengetahui pengaruh dari salah satu variabel independen terhadap variabel dependen secara parsial. Dalam penelitian ini terdapat tiga variabel independen yaitu $E A T, O C F$, dan $D E R$ yang diuji pengaruhnya terhadap variabel dependen $D P S$. Terdapat tiga pengujian secara parsial, yaitu EAT terhadap DPS, OCF terhadap DPS, dan DER terhadap DPS. Data hasil uji t parsial dapat dilihat pada Tabel 10 di bawah ini.

Tabel 10. Hasil Uji t Parsial

\begin{tabular}{|c|c|c|c|c|c|c|}
\hline \multicolumn{7}{|c|}{ Coefficients $^{a}$} \\
\hline \multirow[b]{2}{*}{ Model } & & \multicolumn{2}{|c|}{ Unstandardized Coefficients } & $\begin{array}{c}\text { Standardized } \\
\text { Coefficients }\end{array}$ & \multirow[b]{2}{*}{$t$} & \multirow[b]{2}{*}{ Sig. } \\
\hline & & $B$ & Std. Error & Beta & & \\
\hline 1 & (Constant) & -10.209 & 1.629 & & -6.265 & .000 \\
\hline & LnEAT & .535 & .121 & .565 & 4.411 & .000 \\
\hline & $\mathrm{LnOCF}$ & .000 & .112 & .000 & .004 & 997 \\
\hline & $D E R$ & .102 & .148 & .046 & .690 & 491 \\
\hline
\end{tabular}

Dari Tabel 10. tersebut ditunjukkan bahwa nilai t hitung variabel EAT adalah sebesar 4,411 dan nilai signifikansi sebesar 0,000 berada di bawah nilai $\alpha=0,05$ dan $\beta=0,535$, maka dapat disimpulkan bahwa $\mathrm{H}_{\mathrm{a} 1}$ diterima, yang artinya terdapat pengaruh positif dan signifikan EAT terhadap DPS.

Berdasarkan Tabel 10 tersebut ditunjukkan bahwa nilai t hitung variabel $O C F$ adalah sebesar 0,004 dan nilai signifikansi sebesar 0,997 berada di atas nilai $\alpha=0,05$, maka dapat disimpulkan bahwa $\mathrm{H}_{\mathrm{a} 2}$ ditolak, yang artinya tidak terdapat pengaruh yang signifikan $O C F$ terhadap DPS. Sesuai dengan Tabel 10. tersebut ditunjukkan bahwa nilai thitung variabel $D E R$ adalah sebesar 0,690 dan nilai signifikansi sebesar 0,491 berada di atas nilai $\alpha=$ 0,05 , maka dapat disimpulkan bahwa $\mathrm{H}_{\mathrm{a} 3}$ ditolak, yang artinya tidak terdapat pengaruh yang signifikan $D E R$ terhadap $D P S$.

b. Uji F (Uji Simultan). Uji F bertujuan untuk menguji koefisien regresi secara simultan, yaitu melihat pengaruh semua variabel independen yang terdiri dari $E A T, O C F$, dan $D E R$ secara bersama-sama terhadap variabel dependen yaitu DPS. Dasar pengambilan keputusan uji $\mathrm{F}$ adalah jika nilai signifikansi > 0,05 maka $E A T, O C F$, dan DER secara simultan tidak berpengaruh terhadap DPS. Sebaliknya, jika nilai signifikansi < 0,05 maka $E A T, O C F$, dan DER secara simultan berpengaruh terhadap DPS. Data hasil uji F simultan dapat dilihat pada Tabel 11 sebagai berikut.

Tabel 11. Hasil Uji F Simultan ANOVA ${ }^{a}$

\begin{tabular}{llrrrrr}
\hline Model & & Sum of Squares & df & Mean Square & $F$ & \multicolumn{1}{c}{ Sig. } \\
\hline 1 & Regression & 198.526 & 3 & 66.175 & 25.800 & $.000^{\mathrm{b}}$ \\
& Residual & 430.915 & 168 & 2.565 & & \\
& Total & 629.441 & 171 & & & \\
\hline
\end{tabular}

a. Dependent Variable: LnDPS

b. Predictors: (Constant), DER, LnOCF, LnEAT 
Berdasarkan Tabel 11 tersebut diperoleh nilai $F$ hitung sebesar 25,800 dan nilai signifikansi sebesar 0,000. Dalam pengambilan keputusan hasil uji F secara simultan, nilai signifikansi $F$ hitung yang nilainya 0,000 berada di bawah nilai $\alpha=0,05$, maka dapat disimpulkan bahwa secara simultan variabel independen $E A T, O C F$, dan DER memiliki pengaruh yang signifikan terhadap variabel dependen $D P S$.

5. Pengujian Koefisien Determinasi. Pengujian koefisien determinasi $\left(\mathrm{R}^{2}\right)$ dilakukan dengan tujuan untuk mengetahui besarnya pengaruh variabel-variabel independen terhadap variabel dependen yang digunakan dalam penelitian ini. Nilai dari koefisien determinasi berkisar antara $0-1$. Nilai $\mathrm{R}^{2}$ yang kecil menunjukkan bahwa kemampuan variabel-variabel independen dalam menjelaskan variasi variabel dependen amat terbatas. Sedangkan nilai yang mendekati angka 1 menunjukkan bahwa variabel-variabel independen menjelaskan variasi variabel dependen dengan lengkap. Data hasil uji koefisien determinasi dapat dilihat pada Tabel 12 berikut ini.

Tabel 12. Hasil Uji Koefisien Determinasi

\begin{tabular}{|c|c|c|c|c|}
\hline \multicolumn{5}{|c|}{ Model Summary ${ }^{b}$} \\
\hline Model & $R$ & $R$ Square & $\begin{array}{l}\text { Adjusted } R \\
\text { Square }\end{array}$ & $\begin{array}{l}\text { Std. Error of } \\
\text { the Estimate }\end{array}$ \\
\hline 1 & $.562^{\mathrm{a}}$ & .315 & .303 & 1.60155 \\
\hline
\end{tabular}

Berdasarkan Tabel 12 tersebut di atas, diperoleh besarnya Adjusted $R$ Square $\left(\mathrm{R}^{2}\right)$ adalah 0,303, hal ini berarti bahwa 30,3\% variasi DPS dapat dijelaskan oleh variasi dari tiga variabel independen $E A T, O C F$, dan DER. Sedangkan sisanya $(100 \%-30,3 \%=69,7 \%)$ dijelaskan oleh faktor lain di luar penelitian ini. Standard Error of the Estimate (SEE) sebesar 1,60155. Makin kecil nilai SEE akan membuat suatu model regresi makin tepat dan akurat dalam memprediksi variabel dependen.

Pengaruh Net Income (EAT) terhadap Dividend per Share (DPS). Hipotesis pertama yang menyatakan bahwa terdapat pengaruh positif yang signifikan EAT terhadap DPS dapat diterima. Hal ini dapat dibuktikan dengan tingkat signifikansi variabel $E A T$ pada tabel t yang nilainya sebesar $0,000<\alpha 0,05$ dan koefisien $\beta$ sebesar 0,535 . Variabel $E A T$ memiliki koefisien positif, yang berarti bahwa makin tinggi EAT yang diperoleh perusahaan maka akan mengakibatkan peningkatan DPS. Laba bersih perusahaan sebagai indikator dalam melakukan penilaian atas kualitas kinerja suatu perusahaan dari tingkat laba yang dihasilkan. Informasi laba yang mencerminkan kinerja perusahaan dapat mempengaruhi pembagian dividen. Makin tinggi tingkat laba yang dihasilkan perusahaan maka makin tinggi tingkat dividen yang dibagikan, karena dengan meningkatnya laba bersih yang diperoleh perusahaan maka perusahaan memiliki dana yang lebih besar yang dapat digunakan untuk pembayaran dividen bagi investor sehingga berdampak pada peningkatan pembagian dividen. Hasil penelitian ini mendukung penelitian yang dilakukan oleh Wowor dan Mangantar (2014) yang menyatakan bahwa laba bersih memiliki pengaruh positif yang signifikan terhadap dividend per share. Isnaeni dan Herjdiono (2015) juga melakukan penelitian yang hasilnya adalah laba bersih berpengaruh positif dan signifikan terhadap dividend per share. 
Pengaruh Operating Cash Flow (OCF) terhadap Dividend per Share (DPS). Hipotesis kedua yang menyatakan bahwa terdapat pengaruh positif yang signifikan $O C F$ terhadap $D P S$ ditolak. Hal ini dapat dibuktikan dengan tingkat signifikansi variabel $O C F$ pada tabel t yang nilainya sebesar $0,997>\alpha 0,05$, yang berarti bahwa $O C F$ tidak memiliki pengaruh signifikan terhadap DPS. Walaupun tidak mempunyai pengaruh yang signifikan terhadap $D P S$, dari persamaan regresi linier berganda pada tabel 9. terlihat bahwa koefisien $O C F$ sebesar 0,000 . Koefisien regresi positif $O C F$ dalam persamaan regresi linier berganda tersebut menunjukkan pengaruh positif $O C F$ terhadap $D P S$, dimana makin tinggi arus kas operasi suatu perusahaan akan mengakibatkan meningkatnya DPS. Dividen digunakan sebagai sinyal positif bagi kemampuan manajer dalam mengelola perusahaan. Ketika perusahaan melakukan pembayaran dividen, diperlukan arus kas yang cukup. Perusahaan dengan kinerja yang baik akan menghasilkan arus kas operasi yang tinggi sehingga dapat melakukan pembagian dividen yang tinggi pula. Dengan kata lain, jika arus kas operasi meningkat maka akan meningkatkan dividend per share. Hasil penelitian sesuai dengan penelitian yang dilakukan oleh Ramli dan Arfan (2011) yang menyatakan bahwa arus kas operasi tidak memiliki pengaruh signifikan terhadap dividend per share. Namun, hasil penelitian ini tidak sesuai dengan penelitian Isnaeni dan Herjdiono (2015) yang menunjukkan arus kas operasi berpengaruh signifikan terhadap dividend per share.

Pengaruh Debt to Equity Ratio (DER) terhadap Dividend per Share (DPS). Hipotesis ketiga yang menyatakan bahwa terdapat pengaruh negatif yang signifikan $D E R$ terhadap $D P S$ ditolak. Hal ini dapat dibuktikan dengan tingkat signifikansi variabel $D E R$ pada tabel t yang nilainya $0,491>\alpha 0,05$, yang berarti bahwa $D E R$ tidak memiliki pengaruh yang signifikan terhadap DPS. Meskipun tidak mempunyai pengaruh yang signifikan terhadap $D P S$, dalam persamaan regresi linier berganda pada tabel 9. dapat dilihat bahwa koefisien $D E R$ sebesar 0,102. Koefisien regresi positif $D E R$ dalam persamaan regresi linier berganda tersebut menunjukkan pengaruh positif $D E R$ terhadap DPS, dimana makin tinggi debt to equity ratio suatu perusahaan akan meningkatkan dividend per share. Hal ini menandakan bahwa kenaikan hutang perusahaan tidak selalu memberi dampak pada penurunan dividen, namun dengan $D E R$ yang tinggi akan memberikan kesempatan bagi perusahaan untuk berkembang dan menghasilkan laba yang lebih besar dan dapat meningkatkan pembagian dividennya. Hasil penelitian ini mendukung penelitian yang dilakukan oleh Isnaeni dan Herjdiono (2015) serta Martati (2010) yang menyatakan bahwa debt to equity ratio tidak mempengaruhi secara signifikan dividend per share. Sedangkan penelitian yang dilakukan oleh Ikhsan (2014) menyatakan bahwa debt to equity ratio mempengaruhi secara signifikan dividend per share.

Pengaruh Net Income (EAT), Operating Cash Flow (OCF), dan Debt to Equity Ratio (DER) secara simultan terhadap Dividend per Share (DPS). Berdasarkan hasil analisis regresi linier berganda pada tabel 9., diperoleh nilai koefisien regresi Net Income $\left(\mathrm{X}_{1}\right)$ sebesar 0,535, koefisien regresi Operating Cash Flow $\left(\mathrm{X}_{2}\right)$ sebesar 0,000, dan koefisien regresi Debt to Equity Ratio $\left(\mathrm{X}_{3}\right)$ sebesar 0,102, sedangkan nilai konstantanya adalah 10,209. Maka diperoleh persamaan regresinya $\mathrm{Y}=-10,209+0,535 \mathrm{X}_{1}+0,000 \mathrm{X}_{2}+$ $0,102 \mathrm{X}_{3}+$ e. Artinya adalah apabila Net Income $\left(\mathrm{X}_{1}\right)$ mengalami kenaikan satu satuan maka Dividend per Share (Y) akan mengalami kenaikan sebesar 0,535 satuan, dengan asumsi variabel $\mathrm{X}_{2}$ dan $\mathrm{X}_{3}$ dianggap konstan. Apabila Operating Cash Flow $\left(\mathrm{X}_{2}\right)$ mengalami kenaikan satu satuan maka Dividend per Share (Y) akan mengalami kenaikan 
sebesar 0,000 satuan, dengan asumsi variabel $\mathrm{X}_{1}$ dan $\mathrm{X}_{3}$ dianggap konstan. Apabila Debt to Equity Ratio $\left(\mathrm{X}_{3}\right)$ mengalami kenaikan satu satuan maka Dividend per Share $(\mathrm{Y})$ akan mengalami kenaikan sebesar 0,102 satuan, dengan asumsi variabel $X_{1}$ dan $X_{2}$ dianggap konstan.

Hasil penelitian uji $\mathrm{F}$ menunjukkan bahwa terdapat pengaruh secara simultan $E A T$, $O C F$, dan $D E R$ yang signifikan terhadap DPS pada perusahaan manufaktur yang terdaftar di Bursa Efek Indonesia (BEI) selama periode penelitian tahun 2012-2015. Hasil pengujian tersebut dapat dilihat dari tingkat signifikansi $\mathrm{F}$ hitung yang nilainya $0,000<\alpha$ 0,05 , sehingga dapat dikatakan bahwa semua variabel independen yaitu Net Income (EAT), Operating Cash Flow (OCF), dan Debt to Equity Ratio (DER) memiliki pengaruh secara simultan terhadap variabel dependen Dividend per Share (DPS). Sedangkan berdasarkan uji t secara parsial yang telah disajikan sebelumnya, hanya variabel Net Income (EAT) yang memiliki pengaruh signifikan terhadap Dividend per Share (DPS). Hal ini dapat disebabkan karena variabel Net Income (EAT) memiliki pengaruh yang paling kuat dibandingkan dengan variabel independen lainnya.

Selanjutnya dalam pengujian koefisien determinasi $\left(\mathrm{R}^{2}\right)$, diperoleh hasil Adjusted $R$ Square $\left(\mathrm{R}^{2}\right)$ adalah sebesar 0,303, hal ini berarti bahwa 30,3\% variasi DPS dapat dijelaskan oleh variasi dari ketiga variabel independen $E A T, O C F$, dan $D E R$. Sedangkan sisanya sebesar $69,7 \%$ dijelaskan oleh sebab lain di luar model regresi ini. Jadi, dividend per share pada perusahaan manufaktur yang terdaftar di BEI tahun 2012-2015 dipengaruhi oleh faktor net income, operating cash flow, dan debt to equity ratio sebanyak 30,3\%.

\section{PENUTUP}

Simpulan. Berdasarkan hasil pengujian yang telah dilakukan dapat disimpulkan beberapa hal sebagai berikut: (1) secara simultan, variabel $E A T, O C F$, dan $D E R$ berpengaruh signifikan terhadap DPS; (2) secara parsial, variabel yang berpengaruh signifikan adalah $E A T$, sedangkan $O C F$ dan DER tidak signifikan; (3) hasil koefisien determinasi $\left(\mathrm{R}^{2}\right)$ menunjukkan bahwa pengaruh variabel $E A T, O C F$, dan $D E R$ secara simultan terhadap DPS sebesar $30,3 \%$.

Saran. Saran-saran yang dapat diberikan adalah sebagai berikut: (1) bagi para investor dan calon investor, disarankan untuk tidak hanya mempertimbangkan faktor-faktor seperti net income, operating cash flow, dan debt to equity ratio, tetapi sebaiknya mempertimbangkan faktor lain seperti ukuran perusahaan, suku bunga, tingkat inflasi, rasio likuiditas, profitabilitas, solvabilitas, dan aktivitas; (2) bagi perusahaan, disarankan untuk mengatur kebijakan pembagian dividen yang tepat sehingga dapat meningkatkan kepercayaan dan menarik minat investor untuk berinvestasi dalam perusahaan; (3) bagi peneliti selanjutnya, disarankan untuk menambahkan variabel independen yang diteliti, jumlah sampel dalam jangka waktu penelitian yang lebih lama sehingga diharapkan dapat memperoleh hasil penelitian yang lebih baik lagi.

\section{DAFTAR RUJUKAN}

Gade, H. Muhammad. (2005) Teori akuntansi. Jakarta: Almahira. 16

Ghozali, Imam. (2013) Aplikasi analisis multivariat dengan program IBM SPSS 21. Edisi

7. Semarang: Penerbit Universitas Diponegoro. 19, 97-99 
Gibson, Charles H. (2013) Financial reporting \& analysis. Thirteenth edition. Ohio: South-Western. 285

Guinan, Jack. (2009) The investopedia guide to wall speak. New York: McGraw-Hill. 78

Harahap, Sofian Safri. (2010) Analisis kritis atas laporan keuangan. Jakarta: Rajawali Persada. 257

Ikatan Akuntan Indonesia. (2015) Standar Akuntansi Keuangan: Per Efektif 1 Januari 2015. Jakarta: IAI

Ikhsan, Wan Aulia. (2014) Pengaruh debt to equity ratio (DER), return on investment (ROI), kepemilikan manajerial dan ukuran perusahaan terhadap dividend per share (DPS) pada perusahaan manufaktur yang terdaftar di Bursa Efek Indonesia (BEI). Jurnal Online Mahasiswa (JOM) Bidang Ilmu Ekonomi. 1 (1), 1-15

Irawati, Susan. (2006) Manajemen keuangan. Bandung: PT Pustaka. 64

Isnaeni dan Irine Herjdiono. (2015) "Pengaruh laba bersih, arus kas operasi, leverage dan dividen tahun sebelumnya terhadap dividen tunai (studi pada perusahaan manufaktur di Bursa Efek Indonesia tahun 2010-2013)", Jurnal Prosiding Sendi_U. 1-10

Khan, M.Y. dan P.K. Jain. (2010) Management accounting. Fifth edition. New Delhi: Tata McGraw Hill. 6.24

Libby, Robert, Patricia A. Libby dan Daniel G. Short. (2011) Financial accounting. Seventh edition. New York: McGraw-Hill. 639

Martati, Indah. (2010) Faktor penentu dividend per share perusahaan manufaktur yang terdaftar pada Bursa Efek Indonesia. Jurnal EKSIS. 6 (2),1598-1605

Needles, Belverd E., Marian Powers dan Susan V. Crosson. (2014) Principles of accounting. Twelfth edition. Ohio: South-Western. 86

Pradhono. (2004) Pengaruh economic value added, residual income, earnings, dan arus kas operasi terhadap return yang diterima oleh pemegang saham (studi pada perusahaan manufaktur yang terdaftar di Bursa Efek Indonesia). Jurnal Akuntansi \& Keuangan. 6 (2) 149

Pramesti, Getut. (2016) Statistika lengkap secara teori dan aplikasi dengan SPSS 23. Jakarta: PT Elex Media Komputindo. 67-69

Ramli, M. Ridha dan Muhammad Arfan. (2011) Pengaruh laba, arus kas operasi, arus kas bebas, dan pembayaran dividen kas sebelumnya terhadap dividen kas yang diterima oleh pemegang saham (studi pada perusahaan manufaktur yang terdaftar di Bursa Efek Indonesia). Jurnal Telaah \& Riset Akuntansi. 4 (2) 126-138

Sartono, Agus. (2010) Manajemen keuangan teori dan aplikasi. Edisi keempat. Yogyakarta: BPFE. 66

Sawir, Agnes. (2004) Kebijakan pendanaan dan restrukturisasi perusahaan. Jakarta: PT Gramedia Pustaka Utama. 137-139

Scott, Peter. (2015) Accounting for business. Second edition. New York: Oxford University Press. 190

Weil, Roman L., Katherine Schipper dan Jennifer Francis. (2014) Financial accounting. Fourteenth edition. Ohio: South-Western. 16, 236

Wowor, Andre S. dan Maryam Mangantar. (2014) Laba bersih dan tingkat risiko harga saham pengaruhnya terhadap dividen pada perusahaan otomotif yang terdaftar di Bursa Efek Indonesia. Jurnal EMBA. 2 (4) 13-23

http://www.idx.co.id/ 